\title{
Kebijakan Formulasi Pertanggungjawaban Pidana Terhadap Korporasi
}

\author{
Husni $^{1}$ \\ Dosen Fakultas Hukum Universitas Malikussaleh \\ Kepala PDIH Fakultas Hukum Universitas Malikussaleh \\ husni7790@yahoo.co.id
}

\begin{abstract}
According to criminal law regulation, human is only the subject to be blamed in term of criminal action. A human can be as a guilty party of any criminal case. . However, this regulation has been abandoned by Indonesian law system because of the perspective change that beside human, the corporate bodies are also as the subject of guilty party if the legal regulation is specificly determined by Legal Code in term of specific case. Therefore, based on the legal regulation, the corporate bodies are treated as equal as human in term of the subject of lawsuit so the, the rejection of prosecution toward corporate bodies based on Delinguere University's doctrine- non potest has been changed by accepting the concept of functional doer. (fungtioneel daderschap). Although the constitution considers the corporate bodies as the subject of lawsuit, the responsibility of criminal prosecution will be treated in different way from human as a subjet of lawsuit. Although the corporate bodies can be prosecuted, the issue in implemating the case still remains due to the variation of terminology use. Additionally, the other challange is because the regulation implemented relating to corporate bodies' lawsuit is still not determined specificly in criminal code. It is also insufficience and inconsistent prosecution regulation regarding to corporate body lawsuit.
\end{abstract}

\section{Keywords:}

Formulation policy, criminal law resposibility, corporate bodies.

\begin{abstract}
Abstrak
Dalam Kitab Undang-Undang Hukum Pidana (KUHP) hanya manusia yang dianggap sebagai subyek hukum pidana, artinya bahwa hanya manusia yang dapat dipersalahkan dalam suatu peristiwa tindak pidana. Akan tetapi ajaran ini sudah ditinggalkan oleh doktrin hukum Indonesia, karena telah terjadi pergeseran pandangan bahwa disamping manusia juga badan hukum, perkumpulan atau korporasi dapat menjadi subyek tindak pidana, apabila secara khusus ditentukan dalam undang-undang untuk delik tertentu.Dengan demikian dapat dikatakan bahwa melalui perundang-undangan, korporasi sudah diterima sebagai subyek hukum dan diperlakukan sama dengan subyek hukum alamiah (manusia), jadi penolakan pemidanaan korporasi berdasarkan dokrin universitas delinquere non potest sudah mengalami perubahan dengan menerima konsep pelaku fungsional (fungtioneel daderschap). Meskipun undang-undang menjadikan korporasi sebagai subyek hukum pidana, namun dalam hal pertanggungjawaban pidananya akan berbeda dengan subyek hukum alamiah (manusia). Penempatan korporasi sebagai subyek tindak pidana sampai sekarang masih menjadi masalah, karena istilah yang digunakan untuk korporasi bermacam-macam / tidak seragam, disamping penyebutan korporasi yang bermacam-macam, masalah lain dalam pembahasan pertanggungjawaban pidana terhadap korporasi adalah belum ada aturan pemidanaan umum untuk korporasi dalam KUHP, dan belum adanya pola aturan pemidanaan korporasi yang seragam dan konsisten.
\end{abstract}

Kata Kunci:

Kebijakan Formulasi, Pertanggungjawaban Pidana, Korporasi 


\section{A. PENDAHULUAN}

Seiring dengan perkembangan zaman, maka masyarakat terus berubah, begitu juga dengan kejahatan, perkembangan kejahatan akan selalu mengikuti perkembangan masyarakat. Salah satu bentuk kejahatan yang selalu mengikuti perkembangan masyarakat adalah kejahatan yang dilakukan oleh korporasi. Korporasi tumbuh dan berkembang sebagai lembaga yang mencari keuntungan dengan tidak mengindahkan kerugian yang ditimbulkan bagi masyarakat.

Sejauh ini di dalam Kitab Undang-Undang Hukum Pidana (KUHP) hanya manusia yang dianggap sebagai subyek hukum pidana, artinya bahwa hanya manusia yang dapat dipersalahkan dalam suatu peristiwa tindak pidana. Hal ini terlihat dari penjelasan Memorie van Toelichting (M.v.T) bahwasanya yang menjadi subyek tindak pidana itu adalah manusia. Akan tetapi ajaran ini sudah ditinggalkan oleh doktrin hukum Indonesia, karena dalam terma hukum telah terjadi pergeseran pandangan bahwa disamping manusia juga badan hukum, perkumpulan atau korporasi dapat menjadi subyek tindak pidana, apabila secara khusus ditentukan dalam undang-undang untuk delik tertentu. ${ }^{1}$

Dengan demikian dapat dikatakan bahwa melalui perundangundangan, korporasi sudah diterima sebagai subyek hukum dan diperlakukan sama dengan subyek hukum alamiah (manusia), jadi penolakan pemidanaan korporasi berdasarkan dokrin universitas delinquere non potest sudah mengalami perubahan dengan menerima konsep pelaku fungsional (fungtioneel daderschap).

Meskipun undang-undang menjadikan korporasi sebagai subyek hukum pidana, namun dalam hal pertanggungjawaban pidananya akan berbeda dengan subyek hukum alamiah (manusia). Penempatan korporasi sebagai subyek tindak pidana sampai sekarang masih menjadi masalah, karena istilah yang digunakan untuk korporasi bermacam-macam/tidak seragam,

${ }^{1}$ Sudarto, Hukum Pidana I, Semarang: Yayasan Sudarto Fakultas Hukum Undip, 1990, hlm. 61 
istilah korporasi baru mulai terlihat pada tahun 1997 dalam Undangundang Psikotropika. Disamping penyebutan korporasi yang bermacam-macam, masalah lain dalam pembahasan pertanggungjawaban pidana terhadap korporasi adalah belum ada aturan pemidanaan umum untuk korporasi dalam KUHP, dan belum adanya pola aturan pemidanaan korporasi yang seragam dan konsisten, dalam hal :

- Kapan korporasi melakukan tindak pidana dan kapan dipertanggung- jawabkan, dalam hal ini ada yang merumuskan ada yang tidak;

- Siapa yang dipertanggungjawabkan, dalam hal ini juga ada yang merumuskan ada yang tidak; dan

- Jenis sanksi dan perumusan sanksi, ada yang merumuskan secara alternatif, kumulatif, dan gabungan (alternatif-kumulatif). ${ }^{2}$

Berkaitan dengan hal tersebut di atas, maka terdapat dua pandangan yang berkembang tentang pertanggungjawaban terhadap korporasi. Pendapat pertama, mengatakan bahwa yang dimaksud dengan korporasi adalah suatu kumpulan

2 Barda Nawawi Arief, Kapita Selekta Hukum Pidana, Bandung: Citra Aditya Bakti, 2003, hlm. 230 dagang yang sudah berbadan hukum. Jadi dibatasi bahwa korporasi yang dipertanggung -jawabkan secara pidana adalah korporasi yang sudah berbadan hukum. Alasannya adalah bahwa dengan sudah berbadan hukum, sudah jelas susunan pengurus serta sejauh mana hak kewajiban dalam korporasi tersebut. Pendapat kedua bersifat lebih luas, dimana dikatakan bahwa korporasi tidak perlu berbadan hukum. Setiap kumpulan manusia, baik dalam hubungan suatu usaha dagang ataupun usaha lainnya, dapat dipertanggungjawabkan secara pidana. ${ }^{3}$ Dalam kaitan ini ternyata terdapat kelemahan dalam bidang perundang-undangan di Indonesia, yakni sejauh ini Indonesia belum mempunyai Undang-undang Korporasi, meskipun sudah ada undang-undang tentang Perseroan Terbatas, tetapi belum sepenuhnya mengatur masalah korporasi dan pertanggungjawaban pidananya.

Konsekuensi logis tentang kedudukan korporasi sebagai badan

3 Loebby Luqman, Kapita Selekta Tindak Pidana Di Bidang Perekonomian, Jakarta: Datacom, (tanpa tahun), hlm. 29 
hukum, membawa pengaruh terhadap tindak pidana yang dapat dilakukan oleh korporasi, hal tersebut dikarenakan bahwa tidak semua tindak pidana dapat dilakukan oleh korporasi. Menurut Barda Nawawi Arief, walaupun pada asasnya korporasi dapat dipertanggungjawabkan sama dengan orang pribadi, namun ada beberapa pengecualian, yaitu:

1. Dalam perkara-perkara yang menurut kodratnya tidak dapat dilakukan oleh korporasi, misalnya bigami, perkosaan, sumpah palsu.

2. Dalam perkara yang satusatunya pidana yang dapat dikenakan tidak mungkin tidak mungkin dikenakan kepada korporasi, misalnya pidana penjara atau pidana mati. ${ }^{4}$

Selanjutnya menurut Muladi, segala sanksi pidana dan tindakan pada dasarnya dapat dikenakan pada

\footnotetext{
4 Barda Nawawi Arief, Perbandingan Hukum Pidana, Jakarta : Rajawali Pers, 1990, hlm. 37

${ }^{5}$ Muladi, Prinsip-Prinsip Dasar Hukum Pidana Lingkungan Dalam Kaitannya
}

korporasi, kecuali pidana mati dan pidana penjara. Dalam hal ini perlu di catat bahwa di Amerika Serika di kenal apa yang dinmamakan "corporate death penalty" dan "corporate imprisonmen", yang mengadung pengertian larangan suatu korporasi untuk berusaha di bidang usaha tertentu dan pembatasan-pembatasan lain terhadap langkah-langkah korporasi dalam berusaha.

Lebih lanjut, Muladi menyatakan bahwa pemidanaan terhadap korporasi hendaknya memperhatikan kedudukan korporasi untuk mengendalikan perusahaan, melalui kebijakan pengurus atau para pengurus yang memiliki kekuasaan untuk memutus dan keputusan tersebut telah diterima oleh korporasi tersebut. Penerapan sanksi pidana terhadap korporasi tidak menghapuskan kesalahan perorangan. ${ }^{5}$

dengan UU No.23 Tahun 1997, Bandung Jurnal Hukum Pidana dan Kriminologi, Volume I, Nomor 1/ 1998, hlm. 9 
Sehubungan dengan hal tersebut, Dwidja Priyatno mengatakan bahwa bilamana tindak pidana yang dilakukan korporasi sangat berat, maka di berbagai negara dipertimbangkan untuk menerapkan pengumuman keputusan hakim, sebagai sanksi atas biaya korporasi, sebab dampak yang ingin dicapai tidak hanya yang mempunyai "financial impacts" tetapi juga mempunyai "non financial impacts". ${ }^{6}$

Di Idonesia, perkembangan korporasi sebagai subyek tindak pidana terjadi dalam perundangundangan khusus di luar KUHP, sedangkan KUHP sendiri masih tetap menganut subyek tindak pidana berupa orang, walaupun ada beberapa pasal yang menyangkut/menyinggung korporasi sebagai subyek hukum, akan tetapi yang diancam pidana adalah orang, bukan korporasinya.

Pengaturan/penyebutan korporasi walaupun dengan istilah yang bermacam-macam sebagai subyek tindak pidana dalam perundang-

\footnotetext{
${ }^{6}$ Dwidja Priyatno, Kebijakan Legislasi Tentang Sistem Pertanggungjawaban
}

undangan di Indonesia pada dasarnya dapat digolongkan dalam dua katagori pengaturan, yaitu :

1. Yang menyatakan korporasi sebagai subyek tindak pidana, tetapi yang dapat dipertanggungjawabkan hanya pengurus, antara lain :

a. UU No. 2 Tahun 1951 (UndangUndang Kecelakaan);

b. UU No. 3 Tahun 1951 (UndangUndang Pengawasan Perburuhan);

c. UU No. 12 Tahun 1951 (Undang-Undang senjata api);

d. UU No. 3 Tahun 1953 (UndangUndang Pembukaan Apotek);

e. UU No. 22 Tahun 1957 (Undang-Undang Penyelesaian Perburuhan);

f. UU No. 3 Tahun 1958 (UndangUndang Penempatan Tenaga asing);

g. UU No. 83 Tahun 1958 (Undang-Undang Penerbangan);

Pidana Korporasi Di Indonesia, Bandung: CV. Utomo, 2004, hlm. 119 
h. UU No. 5 Tahun 1964 (UndangUndang Telekomunikasi, berubah mnejadi Undangundang Nomor 5 tahun 1989);

i. UU No. 7 Tahun 1981 (UndangUndang Wajib Lapor Ketenagakerjaan);

j. UU No. 2 Tahun 1981 (UndangUndang Metrologi Legal);

k. $\quad$ UU No. 3 Tahun 1982 (UndangUndang Wajib Lapor Perusahaan);

l. UU No. 7 Tahun 1992 (UndangUndang Perbankan, diganti dengan Undang-Undang Nomor 10 tahun 1998);

2. Yang menyatakan korporasi sebagai subyek dan dapat dipertanggung- jawabkan, antara lain:

a. UU No.7/Drt.1955 tentang Tindak Pidana Ekonomi;

b. UU NO. 5 Tahun 1984 tentang Perindustrian;

c. UU No. 6 Tahun 1984 tentang Pos;

d. UU No. 9 Tahun 1985 tentang Perikanan; e. UU No. 7 Tahun 1992 Tentang Perbankan, diubah dengan UU No. 10 Tahun 1998

f. UU No. 8 Tahun 1995 tentang Pasar Modal;

g. UU No.10 Tahun 1995 Tentang Kepabeanan,

h. UU No. 5 Tahun 1997 tentang Psikotropika;

i. UU No. 35 Tahun 2009 tentang Narkotika;

j. UU No. 32 Tahun 2009 tentang Perlindungan dan Pengeloaan Lingkungan Hidup;

k. UU No. 5 Tahun 1999 tentang Larangan Praktek Monopoli dan Persaingan Usaha tidak sehat;

l. UU No. 8 Tahun 1999 tentang Perlindungan Konsumen;

m. UU No. 31 Tahun 1999 tentang Tindak pidana Korupsi, sebagaimana diubah dengan UU No. 20 Tahun 2001 tentang Tindak Pidana Korupsi,

n. UU No. 8 Tahun 2010 tentang Pencegahan dan Pemberantasan Tindak Pidana Pencucian Uang, 
o. UU No. 20 Tahun 2002 tentang Ketenagalistrikan.

p. UU No.15 Tahun 2003 Tentang Tindak Pidana Terorisme

\section{B. PERMASALAHAN}

Berdasarkan uraian di atas,
maka dapat ditarik beberapa
permasalahan tentang pengaturan
korporasi sebagai subyek tindak
pidana, yaitu:

1. Bagaimana kebijakan formulasi pertanggungjawaban pidana terhadap korporasi dalam hukum pidana di Indonesia saat ini?

2. Bagaimana kebijakan formulasi pertanggungjawaban pidana terhadap korporasi di masa yang akan datang?

\section{TUJUAN PENELITIAN}

1. Untuk mengetahui kebijakan formulasi pertanggungjawaban pidana terhadap korporasi dalam hukum pidana di Indonesia saat ini.

2. Untuk mengetahui kebijakan formulasi pertanggungjawaban pidana terhadap korporasi di masa yang akan datang.

\section{METODE PENELITIAN}

Metode pendekatan yang digunakan dalam penelitian ini adalah pendekatan yang bersifat yuridis normatif, yaitu suatu pendekatan yang secara deduktif menganalisa pasalpasal dalam perundang-undangan pidana positif khususnya dalam KUHP dan Pasal-pasal dalam Perundangundangan pidana positif di luar KUHP.

Mengingat permasalahan dalam penelitian ini difokuskan pada kebijakan formulasi pertanggungjawaban pidana korporasi, maka metode pendekatan yang digunakan adalah pendekatan yuridis normatif yang bertumpu pada data sekunder. Pendekatan dengan menggunakan metode normatif dilakukan dengan cara mengidentifikasikan dan mengonsepsikan hukum sebagai norma kaedah, peraturan perundangundangan yang berlaku serta teoriteori hukum dan asas-asas hukum yang berlaku yang berhubungan dengan permasalahan yang menjadi pokok penelitian. Penelitian terhadap hukum dengan pendekatan demikian merupakan penelitian hukum yang 
normatif atau penelitian hukum yang doktrinal. ${ }^{7}$

\section{E. PEMBAHASAN}

\section{(1) Kebijakan formulasi per- tanggungjawaban pidana ter- hadap korporasi dalam hukum pidana di Indonesia}

Berbicara tentang pertanggungjawaban pidana, maka tidak dapat dilepaskan dari tindak pidana, walaupun pengertian tindak pidana tidak termasuk masalah pertanggungjawaban pidana, tindak pidana hanya menunjuk pada perbuatan yang dilarang, tetapi untuk dapat dipidana harus ada pertanggungjawaban pidana, dan untuk adanya pertanggungjawaban pidana harus jelas terlebih dahulu siapa yang dipertanggungjawabkan. Masalah ini menyangkut subyek tindak pidana yang pada umumnya sudah dirumuskan olek pembuat undangundang untuk setiap tindak pidana.

Dalam perkembangan hukum pidana Indonesia, terdapat tiga sistem pertanggungjawaban pidana

7 Ronny Hanitijo Soemitro, Perbandingan Antara Penelitian Hukum Normatif dengan Penelitian hukum Empiris, Masalah-Masalah Hukum, Nomor 9 Tahun 1991, FH UNDIP, hlm. 44

8 Mardjono Reksodiputro, Kemajuan Pembangunan Ekonomi dan Kejahatan, korporasi sebagai subyek tindak pidana, yaitu :

a. Pengurus korporasi sebagai pembuat, maka penguruslah yang bertanggung jawab;

b. Korporasi sebagai pembuat, maka pengurus yang bertanggung jawab;

c. Korporasi sebagai pembuat dan yang bertanggung jawab. ${ }^{8}$

Dalam sistem pertanggungjawaban yang ketiga, telah terjadi pergeseran pandangan, bahwa korporasi dapat dipertanggungjawabkan disamping manusia alamiah (natuurlijk persoon), jadi penolakan pemidanaan korporasi berdasarkan doktrin universitas delinquere non potest sudah mengalami perubahan dan menerima konsep pelaku fungsional (functioneel daderschap). ${ }^{9}$ Lebih lanjut menurut Muladi, pembenaran pertanggungjawaban korporasi pelaku tindak pidana, dapat didasarkan atas hal-hal sebagai berikut:

Jakarta: Pusat Pelayanan Keadilan dan Pengabdian Hukum UI, 1994, hlm. 72

9 Muladi, Fungsionalisasi Hukum Pidana di Dalam Kejahatan Yang Dilakukan Oleh Korporasi, Makalah seminar Nasional Kejahatan Korporasi FH Undip Semarang, 24 November 1989, hlm. 5 
a. Atas dasar falsafah integralistik, yakni segala sesuatu hendaknya diukur atas dasar keseimbangan, keselarasan dan keserasian antara kepentingan individu dan kepentingan sosial;

b. Atas dasar kekeluargaan dalam pasal 33 UUD 1945;

c. Untuk memberantas anomie of succes (sukses tanpa aturan);

d. Untuk perlindungan konsumen;

e. Untuk kemajuan teknologi. ${ }^{10}$

Dalam rangka mempertanggungjawabkan korporasi secara pidana, juga dikenal beberapa teori tentang pertanggungjawaban pidana korporasi, yaitu :

a. Doktrin Pertanggungjawaban Pidana Langsung (Diredt liability Doctrine) atau Teori Identifikasi (Identification Theory).

Menurut doktrin ini, perusahaan dapat melekukan sejumlah delik secara langsung melalui orang-orang yang sangat berhubungan erat dengan perusahaan dan

10 Hamzah Hatrik, Azas Pertanggungan Korporasi dalam Hukum Pidana (Strict Liability dan Vocrious dipandang sebagai perusahaan itu sendiri. Dalam keadaan demikian mereka tidak sebagai pengganti, dan oleh karena itu pertanggungjawaban perusahaan tidak bersifat pertanggungjawaban pribadi.

b. Doktrin Pertanggungjawaban Pidana pengganti (vicarious liability).

Sistem pertanggungjawaban pengganti adalah pertanggungjawaban seseorang atas kesalahan orang lain. Doktrin ini didasarkan pada "employment principle" bahwa majikan (employer) adalah penanggungjawab utama dari perbuatan para buruh/karyawan, jadi the servant's act is the master's act in law.

c. Doktrin Pertanggunjawaban Pengganti Yang Ketat menurut Undang-Undang (strict Liability)

Pertanggungjawaban pidana korporasi dapat juga sematamata berdasarkan undangundang, terlepas dari doktrin nomor 1 dan nomor 2 di atas
Liability), Jakarta: Raja Garfindo Persada, 1996, hlm. 36. 
(doktrin identifikasi dan doktrin Vicarious liability), yaitu dalam hal korporasi melanggar atau tidak memenuhi kewajiban/kondisi situasi tertentu yang ditentukan oleh undangundang. Pelanggaran kewajiban/kondisi/situasi tertentu oleh korporasi ini dikenal dengan istilah "companies offence", "situational offence" atau "strict liability offence".11

Dengan diterimanya korporasi sebagai konsep pelaku fungsional/ subyek tindak pidana, maka terdapat beberapa masalah yang menyangkut kebijakan formulasi yang perlu dikemukakan dalam hal pertanggung jawaban pidana terhadap korporasi, yaitu:

b. Penyebutan istilah / defenisi korporasi yang tidak seragam.

c. Kapan suatu korporasi dinyatakan sebagai pelaku atau telah melakukan tindak pidana dan kapan suatu tindak pidana telah dilakukan atas nama suatu korporasi.

d. Siapa dan dalam hal bagaimana korporasi dapat diprtanggungjawabkan dan kriteria-kriteria apa yang dapat digunakan sebagai pedoman untuk mempertanggungjawabkan korporasi, sebab masalah pertanggung jawaban selalu dikaitkan dengan masalah kesalahan, yaitu menyangkut masalah kemampuan bertanggungjawab, kesengajaan atau kealpaan dan unsur ketiadaan alasan pemaaf.

e. Pidana apakah yang lebih tepat untuk dikenakan terhadap korporasi, karena dari berbagai formulasi undangundang khusus di luar KUHP selama ini tidak diatur secara khusus jenis pidana untuk korporasi.

f. Di dalam undang-undang Khusus yang memuat ketentuan tentang "pertanggungjawaban pidana korporasi" tidak ada satu pun yang memuat ketentuan tentang bagaimana apabila korporasi (bukan pengurusnya) tidak membayar pidana

11 Barda Nawawi Arief, Sari Kuliah Perbandingan Hukum Pidana, Jakarta: Raja Grafindo, 2002, hlm. 131 
denda, hal ini dapat menimbulkan masalah karena ketentuan umum mengenai pidana denda di dalam pasal 30 KUHP hanya berlaku untuk orang.

Berdasarkan uraian di atas yang menyangkut masalah pertanggungjawaban pidana, ternyata konstruksi yuridis dari semua literatur tentang pertanggungjawaban pidana masih berorientasi pada manusia/ orang. Hal tersebut dapat dimengerti karena ide tentang konstruksi pertanggungjawaban pidana berdasarkan ketentuan umum dalam Pasal 30 KUHP ditujukan untuk subyek hukum yang berupa orang, bukan untuk korporasi.

\section{(2) Kebijakan formulasi per- tanggungjawaban pidana korporasi di masa yang akan datang.}

Untuk mengetahui kebijakan formulasi pertanggungjawaban pidana terhadap korporasi di masa yang akan datang, maka pembahasannya tidak dapat dilepaskan dari Konsep KUHP. Dalam Konsep KUHP 2005, ketentuan mengenai korporasi dan pertanggungjawaban pidananya di atur

12 Rancangan Konsep KUHP 2005, Departemen Hukum dan Hak Asasi Manusia Republik Indonesia, Dirjen dalam beberapa pasal sebagai berikut: ${ }^{12}$

a. Pasal 182:

"Korporasi adalah kumpulan terorganisasi dari orang dan/atau kekayaan, baik merupakan badan hukum maupun bukan badan hukum".

b. Pasal 47:

"Korporasi merupakan subyek tindak pidana".

c. Pasal 48:

“Tindak pidana dilakukan oleh korporasi apabila dilakukan oleh orang-orang yang bertindak untuk dan atas nama korporasi atau demi kepentingan korporasi, berdasarkan hubungan kerja atau hubungan lain, dalam lingkup usaha korporasi tersebut, baik sendiri-sendiri atau bersamasama”.

d. Pasal 49:

"Jika tindak pidana dilakukan oleh korporasi, pertanggungjawaban pidana dikenakan terhadap korporasi dan/atau pengurusnya".

Peraturan Perundang-Undangan, Jakarta : Juli 2005, hlm. 12-13 
e. Pasal 50:

"Korporasi dapat dipertanggungjawabkan secara pidana terhadap suatu perbuatan yang dilakukan untukdan/atau atas nama korporasi, jika perbuatan tersebut termasuk dalam lingkup usahanya sebagaimana ditentukan dalam anggaran dasar atau ketentuan lain yang berlaku bagi korporasi yang bersangkutan".

f. Pasal 51:

"pertanggungjawaban pidana pengurus korporasi dibatasi sepanjang pengurus mempunyai kedudukan fungsional dalam struktur organisasi korporasi".

g. Pasal 52:

(1) Dalam mempertimbangkan suatu tuntutan pidana, harus dipertimbangkan apakah bagian hukum lain telah memberikan perlindungan yang lebih berguna daripada menjatuhkan pidana terhadap suatu korporasi.

(2) Pertimbangan sebagaimana dimaksud pada ayat (1) harus dinyatakan dalam putusan hakim.

h. Pasal 53:

"Alasan pemaaf dan alasan pembenar yang dapat diajukan oleh pembuat yang bertindak untu dan/atau atas nama korporasi, dapat diajukan oleh korporasi sepanjang alasan tersebut langsung berhubungan dengan perbuatan yang didakwakan kepada korporasi".

Dari perumusan konsep diatas terlihat pokok-pokok kebijakan yang diatur adalah :

a. Defenisi tentang korporasi dalam artian luas, baik sebagi badan hukum maupun bukan sebagai badan hukum (Pasal 182).

b. Penegasan korporasi sebagai subyek tindak pidana (Pasal 47).

c. Penentuan kapan korporasi dikatakan telah melakukan tindak pidana (Pasal 48).

d. Penentuan siapa yang dapat dipertanggungjawabkan (Pasal 49).

e. Penentuan kapan korporasi dapat dipertanggungjawabkan (Pasal $50)$.

f. Penentuan kapan pengurus dapat dipertanggungjawabkan (Pasal 51).

g. Penentuan pidana sebagai ultimatum remedium bagi korporasi (Pasal 52).

h. Penentuan alasan pembenar dan pemaaf bagi korporasi (Pasal 53). 
Dari kebijakan formulasi diatas, terlihat bahwa pertanggung jawaban pidana korporasi masih berorientasi pada orang dan belum berorientasi pada pemidanaan terhadap korporasi itu sendiri.

\section{F. PENUTUP}

\section{Kesimpulan}

Dari uraian di atas dapat disimpulkan bahwa kebijakan formulasi pertanggungjawaban pidana korporasi selama ini masih mengalami kelemahan-kelemahan, karena belum ada aturan /pedoman pemidanaan untuk korporasi dalam KUHP, dan di dalam Undang-undang khusus di luar KUHP.

Kebijakan formulasi pertanggungjawaban pidana korporasi masih berorientasi pada orang dan belum berorientasi pada pemidanaan terhadap korporasi itu sendiri, karena tidak diatur secara khusus jenis pidana untuk korporasi dan tidak ada ketentuan mengenai pidana tambahan atau tindakan tata tertib khusus untuk korporasi.

\section{Saran}

Berkaitan dengan kelemahan kebijakan formulasi/legislasi khususnya dalam merumuskan sanksi pidana untuk korporasi yang merupakan kesalahan strategis yang dapat menghambat upaya pencegahan dan penanggulangan serta pemberantasan kejahatan korporasi pada tahap aplikasi dan eksekusi, maka disarankan kepada pemerintah untuk segera melakuan reformulasi kebijakan pertanggungjawaban pidana terhadap korporasi dengan cara mengubah atau menambah beberapa pasal baik dalam KUHP maupun dalam berbagai perundang undangan di luar KUHP yang berkaitan dengan pertanggungjawaban pidana terhadap korporasi, atau segera melakukan pengesahan terhadap Konsep RUU KUHP menjadi KUHP.

\section{DAFTAR PUSTAKA}

Arief, Barda Nawawi, Kapita Selekta Hukum Pidana, Bandung: Citra Aditya Bakti, 2003.

-, Perbandingan Hukum Pidana, Jakarta: Rajawali Pers, 1990

-------, Sari Kuliah Perbandingan Hukum Pidana, Jakarta: Raja Grafindo, 2002

Hatrik, Hamzah, Azas Pertanggungan Korporasi dalam Hukum Pidana (Strict Liability dan Vocrious Liability), Jakarta: Raja Garfindo Persada, 1996 
Luqman, Loebby, Kapita Selekta Tindak Pidana Di Bidang Perekonomian, Jakarta: Datacom, (tanpa tahun)

Muladi, Prinsip-Prinsip Dasar Hukum Pidana Lingkungan Dalam Kaitannya dengan UU No.23 Tahun 1997, Bandung: Jurnal Hukum Pidana dan Kriminologi, Volume I/Nomor 1/ 1998

--------, Fungsionalisasi Hukum Pidana di Dalam Kejahatan Yang Dilakukan Oleh Korporasi, Makalah seminar Nasional Kejahatan Korporasi FH Undip Semarang, 24 November 1989

Priyatno, Dwidja, Kebijakan Legislasi Tentang Sistem Pertanggungjawaban Pidana Korporasi Di Indonesia, Bandung: CV. Utomo, 2004

Rancangan Konsep KUHP 2005 Departemen Hukum dan Hak Asasi Manusia Republik Indonesia, Dirjen Peraturan PerundangUndangan, Jakarta: Juli 2005

Reksodiputro, Mardjono, Kemajuan

Pembangunan Ekonomi dan Kejahatan, Jakarta: Pusat Pelayanan Keadilan dan Pengabdian Hukum UI, 1994

Sudarto, Kapita Selekta Hukum Pidana, Bandung: Alumni, 1981. 